\title{
A nyelv necrosisa mint az arteritis temporalis szokatlan manifesztációja
}

\author{
Sámson Zoltán dr. ${ }^{1}$ - Gábor Beáta dr. ${ }^{2}$ - Görög Petra dr. ${ }^{3}$ \\ Tóth Csaba dr. ${ }^{3}$ - Röthy Ákos dr. ${ }^{4}$ - Lőcsei Zoltán dr. ${ }^{1}$ \\ Markusovszky Egyetemi Oktatókórház, ${ }^{1}$ Általános Belgyógyászati Osztály, \\ ${ }^{2}$ Infektológiai Osztály, ${ }^{3}$ Patológiai Osztály, ${ }^{4}$ Arc-, Állcsont és Szájsebészeti Osztály, Szombathely
}

\begin{abstract}
A szerzők az arteritis temporalis egy ritka, kezdeti diagnosztikai nehézséget okozó, azonban a kortikoszteroidkezelésre jól reagáló manifesztációját mutatják be esetük kapcsán. A kórlefolyás ismertetése mellett röviden összefoglalják a betegség jellemzőit, a patogenezist, a lehetséges terápiát. Orv. Hetil., 2017, 158(2), 77-80.
\end{abstract}

Kulcsszavak: arteritis temporalis, nyelvnecrosis

\section{Tongue necrosis as an uncommon manifestation of temporal arteritis}

Authors present a rare manifestation of the temporal arteritis, wich caused initial diagnostic difficulties, but it responded well for corticosteroid treatment. The features of the disease, pathogenesis, possible therapy are briefly summarized beside the description of clinical course.

Keywords: temporal arteritis, tongue necrosis

Sámson, Z., Gábor, B., Görög, P., Tóth, Cs., Rôthy, Á., Löcsei, Z. [Tongue necrosis as an uncommon manifestation of temporal arteritis]. Orv. Hetil., 2017, 158(2), 77-80.

(Beérkezett: 2016. október 12.; elfogadva: 2016. november 11.)

$\mathrm{Az}$ arteritis (arteriitis) temporalis a leggyakrabban előforduló nem reaktív, ismeretlen etiológiájú arteritis a nyugati világban, ellentétben a szintén óriássejtes Takayasuarteritisszel, ami inkább a Távol-Keleten terjedt el. Elsősorban az 50 év felettiek érintettek, a betegség kialakulása 75 éves korban a leggyakoribb. Incidenciája Európában 10-20/100 000 lakos, az északi országokban gyakoribb, míg délen ritkábban fordul elő [1]. A nemek közti megoszlás a betegségben 3,5:1 (nő:férfi), a dohányzás nők esetében hatszorosra emeli, míg a diabetes mellitus inkább kissé mérsékli a rizikót $[2,3]$.

A betegség a középnagy artériákat érinti, leggyakrabban a felületes artériákat - arteria (a.) temporalis, a. occipitalis -, de ritkábban a mélyebben futó veróerek (a. ophthalmica, aa. ciliares posteriores, a. vertebralis, a. lingualis) is érintettek lehetnek. Mind egyoldali, mind kétoldali megjelenés előfordul. A betegség tünetei az érintett erek lokalizációjának felelnek meg: halántéktáji fejájás, nyaki, fejtető táji fájdalom, hirtelen kialakuló látászavar, rágáskor jelentkező claudicatiós jellegú fájda- lom, amelyet magas Westergreen-érték, esetleg láz kísér. Szokatlan megjelenési formája a betegségnek a nyelv necrosisa, amely a skalpnecrosishoz hasonlóan az arteritis temporalis legritkább manifesztációja $[3,4]$.

\section{Esetismertetés}

A 72 éves nőbeteg három hete tartó tompa fejfájás, hőemelkedés, változó mértékú fájdalmas nyelvduzzanat miatt jelentkezett vizsgálatra. A kórelózményben asthma bronchiale miatti gondozás, gastrooesophagealis refluxbetegség, cataracta miatti mútét és coxarthrosis miatt totális endoprothesis-beültetés szerepelt. A más intézményben végzett sürgősségi vizsgálatok során - mellkasröntgenen, koponya CT-n - kóros nem volt. Laboratóriumi leleteiból magas C-reaktív protein $(196 \mathrm{mg} / \mathrm{L})$ és Westergreen-érték $(70 \mathrm{~mm} / \mathrm{h})$, leukocytosis $(11,5-18,5$ G/L) emelhető ki. Sürgősséggel elvégzett anti-DNS-, anti-MPO-, anti-PR3-, anti-GBM-antitest-vizsgálatok és antifoszfolipidantitest-vizsgálatok negatívak lettek. A la- 
boratóriumi eredmények és a klinikai kép alapján infekciót valószínúsítettek, felmerült meningitis, majd abscessus lehetősége is, így kezdetben iv. ceftriaxon-, majd később amoxicillin-klavulánsav antibiotikum-terápiát és nem szteroid gyulladásgátlót alkalmaztak. Nem javuló állapot miatt később infektológiai osztályos felvételre került, ekkor a terápiát flukonazollal és kortikoszteroiddal egészítették ki. Diagnosztikus lumbálpunkció során neuroinfekció nem igazolódott. Prokalcitoninemelkedés nem volt. A nyelv duzzanata miatt több alkalommal történt fül-orr-gégészeti vizsgálat, majd nyaki ultrahang és MR. Térfoglaló folyamat, abscessus nem ábrázolódott, csak apró submentalis nyirokcsomót írtak le. Az alkalmazott terápia mellett a gyulladásos aktivitás mérséklődött, de a felmerülő gombás infekció gyanúja miatt a kortikoszteroid dózisát csökkentették.

A beteg családi ok miatt kórházunkba került áthelyezésre. Ekkori laborparaméterekben is a magas CRP-érték, leukocytosis, balra tolt minőségi vérkép emelendők ki. A fizikális vizsgálat során duzzadt, szürkésfehér necroticus lepedékkel fedett, halvány, fájdalmas nyelv volt látható (1. ábra), a bal oldali temporomandibularis ízület érzékenynek bizonyult, illetve bal oldalon, homloktájon érzékeny köteg volt tapintható. A nyelven észlelhető fájdalmas ulceratio miatt a táplálkozása is nehézkes volt, csak folyékony, pépes táplálékot tudott fogyasztani. Az elváltozás a beszédét, a szavak kiejtését is jelentősen nehezítette.

Fentiek alapján arteritis temporalis lehetősége felmerült, emiatt az érintettnek tûnő bal oldali arteria temporalis biopsziájára került sor. A metilprednizolon dózisát emeltük, alacsony dózisú acetilszalicilsavval és preventív dózisú alacsony molekulasúlyú heparinnal (LMWH) egészítettük ki a kezelést. Diagnosztikus problémát jelentett a nyelven észlelhető elváltozás. A nyelven látható eltérés az arteria lingualis ellátási területére korlátozódott, mindkét oldali arteria lingualis érintettsége merült fel, amelyre irodalmi adat is rendelkezésre állt [5-7]. Szemészeti konzílium az arteria ophthalmica területi vasculitist kizárta. Az alkalmazott antimikrobás terápiát leállítottuk, tekintve, hogy a korábban vett, időközben elkészült leoltások bakteriális vagy gombainfekciót nem igazoltak. $1 \mathrm{mg} /$ ttkg dózisban intravénás metilprednizolont alkalmaztunk, emellett nemcsak a laboratóriumi leletek váltak fiziológiássá, valamint fejfájása szûnt gyorsan, de a nyelvet érintő klinikai tünetek lassú javulása, a nyelv granulációja is elkezdődött, ami a diagnózist megerősítette. A kórszövettani eredmény is alátámasztotta az arteritis temporalis diagnózisát (2. ábra). A beteget per os szteroid- és D-vitamin-kezeléssel otthonába bocsátottuk. Ambuláns ellenőrzése során további fokozatos javulás észlelhető, a szteroiddózis lassú fokozatos csökkentése sem okozott relapsust. A nyelven újabb fekély már nem jött létre, azonban a korábbi necrosis következtében kialakult hegesedés a szerv múködését kissé korlátozza, a táplálkozásban nehézséget okoz.

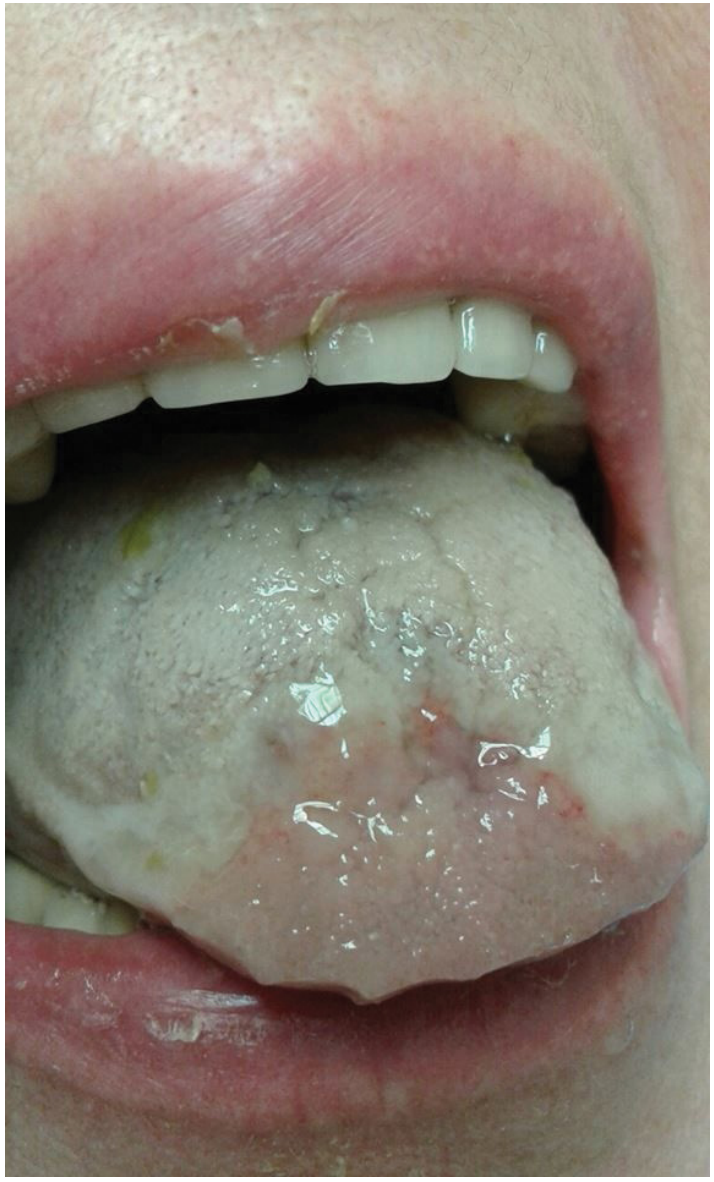

1. ábra

Éles szélú, anaemiás, necroticus felületû terület a nyelven. A nyelvcsúcs megkímélt, mivel a frenulum felól a vérellátása megmaradt

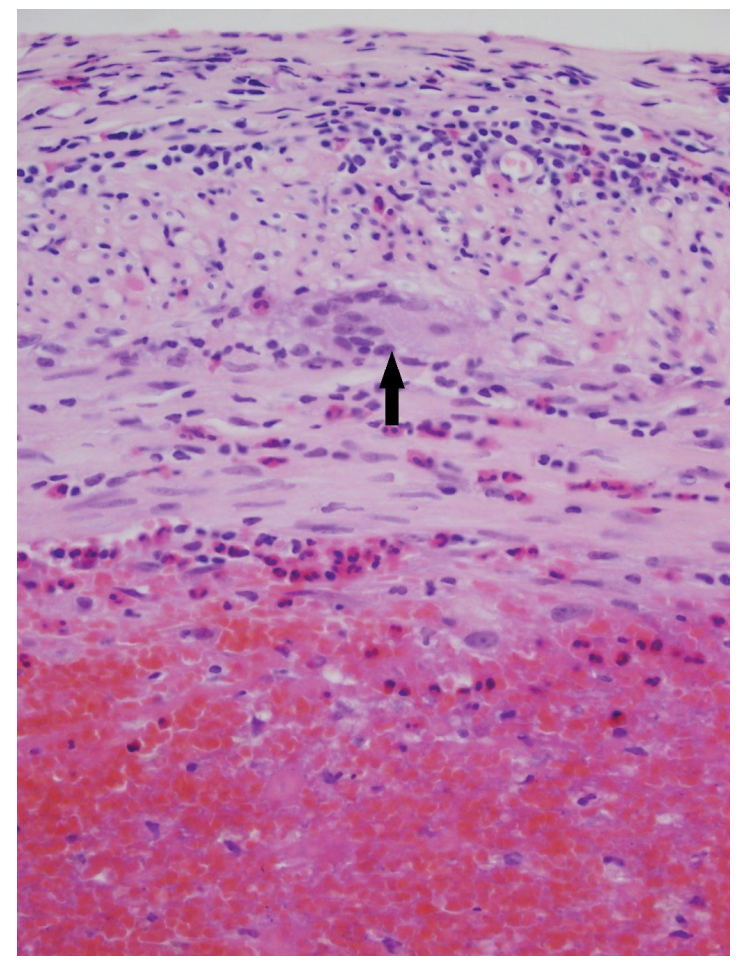

2. ábra 


\section{Megbeszélés}

$\mathrm{Az}$ arteritis temporalis kóroka nem ismert. Egyes feltételezések szerint bizonyos genetikai hajlam (HLA-DR4 haplotípus esetén gyakoribb a betegség) mellett bekövetkező intimasérülés indítja el az artériafalban a gyulladást, amely transmuralis, esetenként szegmentális, de hosszabb érszakaszt is érinthet [3]. A betegség kialakulásában egyes szerzők szerepet tulajdonítanak az immunrendszer és az érfal párhuzamos öregedésének [8]. Más közlemények felvetik elsősorban intracelluláris kórokozók (varicella-zoster vírus, Chlamydia pneumoniae) lehetséges kóroki szerepét $[9,10]$. A celluláris immunválasz az alapvető, elsősorban T-helper 1 és 17 sejtek, makrofágok mutathatók ki a gyulladás korai fázisában, idegen test típusú többmagvú óriássejtek később jelennek meg. A citokinek közül helyileg az IL-1, IFN- $\gamma$, IL17 szerepe döntő jelentőségü, a TNF- $\alpha$ kevésbé meghatározó. A szisztémás tünetek kialakulásában elsősorban az IL-1 és IL-6 játszik szerepet. A gyulladásos válasz során termelt platelet-derived growth factor (PDGF) és az intimában lévő makrofágok által termelt vascular endothelial growth factor (VEGF) koncentrikus intimamegvastagodás kialakulásához vezet. A mediában a makrofágok által termelt mátrixmetalloproteinázok okoznak károsodást. Az érfalban kialakult elváltozások végül stenosishoz, occlusióhoz vezetnek $[3,4,7]$.

A diagnózis gyors felállítása, a korán elkezdett kezelés a maradandó szervkárosodás megelőzése szempontjából fontos. A diagnózis az American College of Rheumatology kritériumrendszerén alapszik $[4,11]$ (1. táblázat). Az ötből három kritérium megléte 93,5\% szenzitivitással és 91,2\% specificitással különíti el az arteritis temporalist a többi vasculitistől $[4,11]$.

A diagnózis felállításához igénybe vehetők különböző képalkotó vizsgálatok is: ultrahang, angiográfia, mágneses rezonancia, MR-angiográfia, esetleg pozitronemiszsziós tomográfia (FDG-PET), bár ezek általában csak kiegészítő eljárások.

$\mathrm{Az}$ arteritis temporalis a polymyalgia rheumaticával rokon betegség, egyes szerzők a kettőt egy betegség különböző manifesztációjának, mások egymással közeli rokonságban álló kórképnek tartják.

A kezelésben jelenleg is elsőnek választandó a kortikoszteroidterápia, emellett a DMARD-terápiák közül a methotrexat az elterjedt, kisebb gyakorisággal

1. táblázat $\mid A z$ arteritis temporalis diagnosztikus kritériumai

1. 50 év felett jelentkező tünetek.

2. Új keletú vagy megváltozott fejfájás.

3. Arteria temporalis abnormalitás, érzékenység, fájdalom, csökkent pulzáció, ami nem az arteriosclerosissal függ össze.

4. $50 \mathrm{~mm} / \mathrm{h}$ feletti Westergreen-érték.

5. Artériabiopszia során granulomatosus gyulladás mononukleáris sejtes infiltrációval, rendszerint sokmagvú óriássejtekkel. azathioprin kerül alkalmazásra. A citosztatikumok kedvező hatását nem sikerült bizonyítani $[2,4,12]$. A biológiai terápiákkal kapcsolatban egyelőre kevés és kis betegszámú vizsgálat, csekély tapasztalat áll rendelkezésre, tocilizumabbal történt kis betegszámú vizsgálatok során biztató eredmények láttak napvilágot [13].

A kórkép legismertebb és súlyosabb szövődménye az arteria ophthalmica érintettsége, ami korai agresszív terápiát tesz szükségessé a kialakuló látásvesztés megelőzésére. Az arteria lingualis érintettsége ritkán előforduló manifesztációnak tekinthető. Amennyiben a betegség diagnózisa felállítható a klasszikus kritériumrendszer alapján, a nyelven észlelhető elváltozás a kórképbe beilleszthető, egyéb betegség keresése nem szükséges, nehogy a kezelés elkezdését szükségtelenül késleltesse. A további kivizsgálás a kezeléssel párhuzamosan folytatható. Differenciáldiagnosztika szempontjából a nyelv vérellátását károsító egyéb kórképek jönnek számításba, például elhúzódó kardiogén vagy szeptikus sokk, essentialis thrombocytosis, disszeminált intravascularis coagulatio $[14,15]$.

A nyelvnecrosis a nemzetközi irodalom szerint is az arteritis temporalis legritkább manifesztációjának tekinthető, 1964 óta eddig összesen 67 esetet írtak le. Hazai közlemény ezzel kapcsolatban még nem született tudomásunk szerint, emiatt értékeltük úgy, hogy fenti esetünk ismertetésre érdemes.

Anyagi támogatás: A közlemény megírása anyagi támogatásban nem részesült.

Szerzôi munkamegosztás: S. Z.: A közlemény első változatának megfogalmazása. L. Z.: A közlemény végleges formába öntése. G. B.: A beteg kórtörténetének, az irodalomnak a feldolgozása. G. P., T. Cs:. A szövettani lelet értékelése. A cikk végleges változatát valamennyi szerző elolvasta és jóváhagyta.

Érdekeltségek: A szerzőknek nincsenek érdekeltségeik.

\section{Irodalom}

[1] González-Gay, M. A., Garcia-Porria, C.: Epidemiology of the vasculitides. Rheum. Dis. Clin. North Am., 2001, 27(4), 729749.

[2] Mythili Seetharaman, C., Foster, C. S., Albertini, J. G., et al.: Giant cell arteritis (temporal arteritis). Medscape, 2015. Available from: http://emedicine.medscape.com/article/332483-overview

[3] Nordborg, C., Nordborg, E., Petursdottir, V.: Giant cell arteritis. Epidemiology, etiology and pathogenesis. APMIS, 2000, 108(11), 713-724.

[4] Zeher, M., Husz, L., Varju, C., et al.: Polymyalgia rheumatica and temporal arteritis. In: Czirják, L. (ed.): Clinical immunology. [Polymyalgia rheumatica és arteritis temporalis. In: Czirják, L. (ed.) Klinikai immunológia (szerk.): Medicina Könyvkiadó, Budapest, 2006, 235-237. [Hungarian] 
[5] Brodmann, M., Dorr, A., Hafner, F., et al.: Tongue necrosis as first symptom of giant cell arteritis (GCA). Clin. Rheumatol., 2009, 28(Suppl. 1), 47-49.

[6] Biebl, M. O., Hugl, B., Posch, L., et al.: Subtotal tongue necrosis in delayed diagnosed giant-cell arteritis: a case report. Am. J. Otolaryngol., 2004, 25(6), 438-441.

[7] Zaragoza, J. R., Vernon, N., Ghaffari, G.: Tongue necrosis as an initial manifestation of giant cell arteritis: case report and review of the literature. Case Rep. Rheumatol., 2015, 2015, Article ID 901795

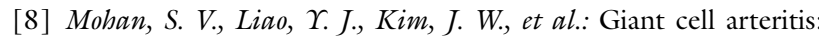
immune and vascular aging as disease risk factors. Arthritis Res. Ther., 2011, 13(4), 231.

[9] Nagel, M. A., Khmeleva, N., Boyer, P. J., et al.: Varicella zoster virus in the temporal artery of a patient with giant cell arteritis. J. Neurol. Sci., 2013, 335(1-2), 228-230.

[10] Hangeberg, G., Bie, R., Nordbø, S. A.: Temporal arteritis associated with Chlamydia pneumoniae DNA detected in an artery specimen. J. Rheumatol., 2001, 28(7), 1738-1739.
[11] Hunder, G. G., Bloch, D. A., Michel, B. A., et al.: The American College of Rheumatology 1990 criteria for the classification of giant cell arteritis. Arthritis Rheum., 1990, 33(8), 1122-1128.

[12] Dasgupta, B., Borg, F. A., Hassan, N., et al.: BSR and BHPR guidelines for the management of giant cell arteritis. Rheumatology (Oxford), 2010, 49(8), 1594-1597.

[13] Evans, J., Steel, L., Borg, F., et al.: Long-term efficacy and safety of tocilizumab in giant cell arteritis and large vessel vasculitis. RMD Open, 2016, 2(1), e000137.

[14] Hulstaert, E., Roggeman, E., Beeckman, A. S., et al.: Ischaemic necrosis of the tongue as a rare complication of cardiogenic shock. Acta Clin. Belg., 2015, 70(6), 436-439.

[15] Cho, J., Sung, K., Lee, D.: Ischemic necrosis of the tongue in surgical patients with septic shock: a case report. BMC Surg., 2016, $16(1), 48$.

(Lőcsei Zoltán dr., Szombathely, Markusovszky u. 5., 9700 e-mail: locsei.zoltan@markusovszky.hu)

A Semmelweis Egyetem Általános Orvostudományi Kara örömmel tesz eleget annak a hagyománynak, hogy volt diákjait jubileumi díszoklevéllel tünteti ki.

Kérjük ezért azokat az orvosokat, akik diplomájukat az egyetem jogelődjénél, a BUDAPESTI KIRÁLYI MAGYAR PÁZMÁNY PÉTER TUDOMÁNYEGYETEMEN, a PÁZMÁNY PÉTER TUDOMÁNYEGYETEMEN, illetve a BUDAPESTI ORVOSTUDOMÁNYI EGYETEMEN 1942-ben

1947-ban

1952-ben

1957-ban

1967-ban

szerezték meg, és szakterületükön legalább 30 évig dolgoztak, nyújtsák be kérelmüket a platina, rubin, vas, gyémánt, illetve arany díszoklevél elnyerése érdekében lehetőleg 2017. április 30-ig, a következő címre, az alábbi jelentkezési lapon.

A jubileumi díszoklevelek átadására elöreláthatóan októberben kerül sor.

A pontos időpontról meghívó útján küldünk értesítést.

\section{Semmelweis Egyetem Általános - Orvostudományi Kar \\ OM azonosító: FI62576 \\ Dékáni Hivatal \\ 1085 Budapest, Üllői út 26. vagy 1428 Budapest Pf. 2.}

JELENTKEZÉSI LAP

arany, gyémánt, vas, rubin és platina díszoklevélhez

NÉV

(névváltoztatás feltüntetésével)

Születési idő:

Diploma kelte:

Lakcím:

Telefonszám:

E-mail cím:

Utolsó munkahely:

Rövid szakmai önéletrajz:

Dátum: 